\title{
An Approach to Understand Rural Advisory Services in a Decentralised Setting
}

\author{
Julien Lamontagne-Godwin ${ }^{1,2, *}$, Peter Dorward ${ }^{2}$, Irshad Ali ${ }^{3}$, Naeem Aslam ${ }^{3}$ and \\ Sarah Cardey ${ }^{2}$ \\ 1 CABI, Surrey TW20 9TY, UK \\ 2 School of Agriculture, Policy and Development, University of Reading, Reading RG6 6AH, UK; \\ p.t.dorward@reading.ac.uk (P.D.); S.p.cardey@reading.ac.uk (S.C.) \\ 3 CABI, Satellite Town, P.O. Box 8, Rawalpindi, Pakistan; I.ali@cabi.org (I.A.); N.Aslam@cabi.org (N.A.) \\ * Correspondence: j.godwin@cabi.org
}

Received: 26 February 2019; Accepted: 21 March 2019; Published: 26 March 2019

\begin{abstract}
As populations increase, so do the challenges in feeding the world. Rural Advisory Services (RAS) contribute positively to food security by ensuring rural populations have access to vital knowledge increasing yields and rural incomes. For historical reasons however, national RAS have often developed into complex networks of stakeholders which can confuse, and even in some cases provide conflicting advice. In order to improve internal and external knowledge of an advisory service, this article investigates the benefits and limitations of an approach that combines qualitative and quantitative stakeholder perception activities at a local and national level. Local and national workshops were held using focus group and open fora techniques in order to portray and visualise a crop health advisory system in Pakistan, a dynamic and complex case study. The approach manages to expose key differences between local and national perceptions of a crop health RAS: whilst both local and national workshop participants decidedly agree on the importance of local (provincial and district level) extension departments, local perceptions clearly identified the strength and value of private sector and community level interactions. At the national workshop, interpretations of ground level activities were vague, yet their mentions of microcredit initiatives, large scale Non-Government Organisation activities and semi-autonomous institutions demonstrate knowledge at a different scale. This approach demonstrates the value of an accessible methodology to measure and understand RAS. Whilst this approach is a key component in assessing the system's dynamism prior to any future development initiative, it needs to refine its integration of gendered perceptions.
\end{abstract}

Keywords: rural advisory services; crop health; methodology; stakeholder perceptions; Pakistan

\section{Introduction}

As global populations are projected to rise (Cleland and Machiyama 2017), the challenge of feeding the world takes centre stage (Sustainable Development Goals 2017). It is incumbent on the international community to focus on much narrower objectives to achieve this daunting target. For example, crop losses due to pests, diseases and weeds, whose effects have been shown to reduce agricultural productivity by up to $40 \%$ worldwide (Oerke 2006; War et al. 2016), is an issue that causes many food insecurity challenges. While industrial food systems involving major commercial farms continually develop comprehensive innovations to reduce pest, disease and weed impacts, they represent only a small proportion of food systems in lower income countries. Up to 500 million smallholder farms supply food to over 2 billion people in Africa and Asia (International Fund for Agricultural Development 2013). They are usually located in isolated rural areas, and unlike large scale commercial enterprises, are not embedded in sophisticated knowledge 
systems that inform them of the latest knowledge and innovations. Therefore, any serious national efforts to reduce pests, disease and weeds' impacts must take communication with smallholder agriculture into consideration.

Rural advisory services (RAS) provide information and support to rural populations on a range of different social, economic and environmental subjects (adapted from Leeuwis and van den Ban 2004; Peterman et al. 2011; Global Forum of Rural Advisory Services 2016), including how to reduce crop losses and consequently increase household income. These services are carried out through field visits; organised group meetings; demonstration plots and increasingly the use of information communication technologies using mass media communications. In the context of crop health, the extension worker is crucial in the information delivery pathway (Rivera 2011). Indeed, advisory services are sometimes solely defined by the presence of agricultural extension agents, and are usually considered the main, or only, pathway to information for the majority of rural households (Anaeto et al. 2012). Traditionally designed to provide information on plant health management (Jones and Garforth 1997), the role of the agricultural extension officer is nevertheless evolving.

Agricultural information needs have increased in complexity recently because of a greater awareness by the farmer of the range of issues to consider, and an increase in communications channels to utilise (Rossi et al. 2012). For example, farmers around the world want to know for their location where to get the best seeds or the latest varieties; which agricultural inputs to use; what the weather forecast is for the next few weeks; what are the diseases and pests affecting their crops; and where should they sell their products for the best price. Each question may require inputs from, and be supplied by, different sets of institutional actors that have access to the relevant information, and may use different communication channels. The traditional role of the extension officer may not be able to satisfy these evolving and complex demands in the field at present. Moreover, agricultural extension officers are increasingly being used for other field related activities, such as census-taking or human health campaigns (Anaeto et al. 2012), which can further add to their demanding roles, and can reduce morale (Rivera 2011).

Therefore, to cope with farmers' complex needs and within a climate of reduced public expenditures in RAS, the set of institutional and organisational actors that compose RAS at both national and local levels has evolved dramatically in the last few decades (Rivera 2011). What was traditionally a public organisational activity around the world now regularly includes the private sector, civil society and community-led enterprise (Sutherland et al. 2013). In order to provide a more comprehensive picture of the knowledge pathways that undoubtedly improves service quality, studies of RAS systems need to consider a variety of local and national stakeholders due to country systems' heterogeneity (Schrempf et al. 2013). Moreover, analyses must consider the interactions between these stakeholders, to identify gaps and opportunities to improve efficiency (Spielman et al. 2009).

This paper aims to visualise, quantify and analyse multisectoral interactions between various layers of administrations, agencies and institutions in the crop health advisory system in a decentralised nation model. In doing so, the paper suggests a novel approach to represent local and national perceptions of a rural advisory service. This approach (built upon Kania et al. 2014 and Fanzo et al. 2015) can enable analyses to understand intuitive and counter-intuitive complexities of decentralisation in different knowledge systems, both federally and locally.

In order to test this approach, it was important to use a decentralised country (at least regarding crop health) with a strong network of local and federal actors already in place. The following section outlines the rationale behind using Pakistan as a test country, not only due to its decentralised status, strong crop health system, but also its present status in CABI's Plantwise programme (www.plantwise.org). This initiative is focused on the development of a touchpoint mechanism to increase farmer knowledge, but is supported by its activities centred around its sustainable integration into crop health RAS (Danielsen and Matsiko 2016). Testing the approach according to its enterprise would make an interesting case study. 
Institutionally and economically, using Pakistan as a case study would offer some interesting insights. Firstly, agriculture accounts for $21 \%$ of the Gross Domestic Product (GDP) and raises $80 \%$ of the country's total export earnings. In Punjab alone, 68 million people are located in a rural setting and engaged in some form of rural activity, and RAS are a vital component of the country's economic, social and political well-being (FAO 2015). Secondly, with a newly reorganised extension system due to the 18th Constitutional Amendment passed by the Parliament in 2010, organisational procedures and mandates are occasionally unclear (Khan 2015). The federal Ministry of National Food Security and Research (MNFSR) remains the primary agricultural authority in the land for plant health activities, and the social science, extension and marketing wing of the Pakistan Agricultural Research Council (PARC) oversees public rural advisory services. Provinces and districts are given increased autonomy to plan, develop and execute their own crop health projects (Shahbaz and Ata 2014; Ali et al. 2011) and perform monitoring, detection and communications activities (Department of Agricultural Extension Punjab 2016). Thirdly and finally, discussions between and within public, private and non-governmental stakeholders on the collaborative approaches to knowledge delivery have traditionally been identified as a weak spot in the country's past activities in agriculture (Davidson et al. 2001; Looney 1999; Chauhan 2014). Indeed, whilst RAS are a public sector activity that engage with many different actors, access to agricultural information is low, and even more so for women in rural households (Hassan et al. 2007; Chauhan 2014; Lamontagne-Godwin et al. 2018). An analysis of local and national perceptions of Pakistan's crop health advisory services system would allow Pakistani decision makers to understand how local or national actors visualise RAS, it would also underline strengths, weaknesses and key interactions in their decentralised economy

The approach conducts this pilot through the lens of the Plantwise programme (Plantwise 2015). Since 2011, this initiative has focused on improving the transfer of knowledge between extension agents and farmers on crop pests, diseases and weeds in over 30 countries. It focuses on training local extension officers to hold weekly field clinics called 'plant clinics'. These are set up in convenient locations for farmers to bring affected samples of their crop and receive symptom-based diagnoses and recommendations on how to prevent, monitor and control the problem. This in turn helps public rural advisory services focus their research and development efforts on topical problems (Finegold et al. 2015), critique their own strengths and deficiencies (Mur et al. 2015), and ensures extension workers get more inclusive access to farmers with crop health problems (Lamontagne-Godwin et al. 2017). In Pakistan, Plantwise has registered over 100,000 queries from farmers in its 500+ clinics since 2011, and has buy-in from federal and provincial (Sindh and Punjab) authorities. Its wide-ranging activities on targeted crop health problems and overall systems' development is particularly important considering the administrative and political calls for change in this sector (U1-Haq et al. 2014). However, as with any programme, the question of the programme's long-term sustainability remains. From a practical perspective, this study's results can help Plantwise better understand a country's perception of the crop health advisory services, its integration into the perceived system, and thereby increase the likelihood of programme sustainability in the federal echelons of the country. It can also serve as a vital lesson for other country programmes (and possibly other external initiatives) at various stages of their national integration and sustainability journeys. Moreover, utilising Plantwise as a case study helps the approach focus on the subtle differences between local and national perceptions of the crop health RAS.

The paper firstly discusses the combination and justification of the methodologies used in this approach. The study then focuses on the results obtained at local and national workshops, and analyses sectoral responses. Finally, the authors discuss the use of this novel approach to not only highlight key points pertaining to decentralisation in theory and in Pakistan, but also to identify an initiative's place and durability in a system. 


\section{Methods}

The study was conducted over the period of June 2014 to June 2015 in the Punjab province of Pakistan. It used desk reviews and informal discussions with key individuals lasting between 30 and 60 min to identify and invite key stakeholders to workshops in July and October 2015 in Jhang and Bahawalpur districts. These districts were selected for the study because of their comparable agro-climatic, economic, agricultural and infrastructural profiles.

Jhang and Bahawalpur districts were chosen for a variety of reasons. The two districts are part of a wider study on the gendered impact of the Plantwise programme (www.plantwise.org) at the institutional and individual level, Jhang being the control site and Bahawalpur the test site (Lamontagne-Godwin et al. 2018). Bahawalpur was chosen specifically because it is the oldest running Plantwise programme district in Pakistan, and gives the wider study the best chance to understand the programme's integration in Pakistani RAS.

Both districts have a similar population size, density, and proportion of urban to rural population (Pakistan Bureau of Statistics 2019). From a socio-economic perspective, both districts have a similar incidence of food poverty in farming households (31\% and 35\% respectively (Qureshi and Arif 2001), and at the household level, have similar family sizes, and percentage of illiteracy (Amjad et al. 2008).

Local focus groups were composed of public sector staff, while the national workshop had a wide range of stakeholders present (Table 1). Unfortunately, organisations chose to invite male participants for the national workshop and many female agricultural officers were in the field during wheat quota inspections for the local focus group discussions. The authors did not achieve the attempted gender balance in the study. Two women, an agricultural extension agent working for the Provincial Directorate of Extension and Adaptive Research (PDEAR), and an assistant district director for the Provincial Directorate of Pest Warning (PDPW), attended the Jhang local workshop, meaning that results cannot disaggregate the data quantitatively, but attempt a qualitative assessment.

Table 1. Composition of national and local workshop participants.

\begin{tabular}{ccccc}
\hline \multirow{2}{*}{ Background Information } & National Workshop & \multicolumn{2}{c}{ Local Workshop } \\
\cline { 2 - 5 } & Total & Total & \multicolumn{2}{c}{ Districts } \\
\cline { 3 - 5 } & & & Jhang & Bahawalpur \\
\hline Number of respondents & 25 & 19 & 10 & 9 \\
Number of men & 25 & 17 & 8 & 9 \\
Number of women & 0 & 2 & 2 & 0 \\
Number of groups & 1 & 7 & 3 & 4 \\
Number of all male groups & 1 & 6 & 2 & 4 \\
Number of all female groups & 0 & 1 & 1 & 0 \\
Number of high-level decision makers & 19 & 5 & 4 & 1 \\
Number of middle level workers & 6 & 11 & 4 & 7 \\
Number of low-level workers & 0 & 3 & 2 & 1 \\
Number of post graduate education holders & 25 & 12 & 6 & 6 \\
Number of graduate education holders & 0 & 4 & 2 & 2 \\
Number of diploma holders & 0 & 3 & 2 & 1 \\
Number of different departments represented & 19 & 5 & 3 & 2 \\
Median years of experience in extension & N/A & 13.5 & 16 & 11 \\
Average years of experience in extension & N/A & 14 & 16 & 12 \\
\hline
\end{tabular}

In order to be comparable, local and national activities followed the same process. Focus groups workshops were held in the executive district offices in both Jhang and Bahawalpur. They lasted approximately $3 \mathrm{~h}$ each. The session was divided into three sections: (a) identify key stakeholders and their roles in the rural advisory services related to crop health; (b) identify their interests and influences in the system; and (c) map stakeholders according to the strength and nature of their linkages. The activities were demonstrated and discussed beforehand to ensure that each individual 
had a clear understanding of what was expected. Data were recorded through the use of paper graphs, similar to Figures 1 and 2, interaction matrices, and English-speaking rapporteurs were asked to describe the results of focus group activity to ensure clarity. Summary sessions, explaining what had been discussed, and clarifying specific points, were conducted at the end of every section to improve the trustworthiness and reliability of the data.

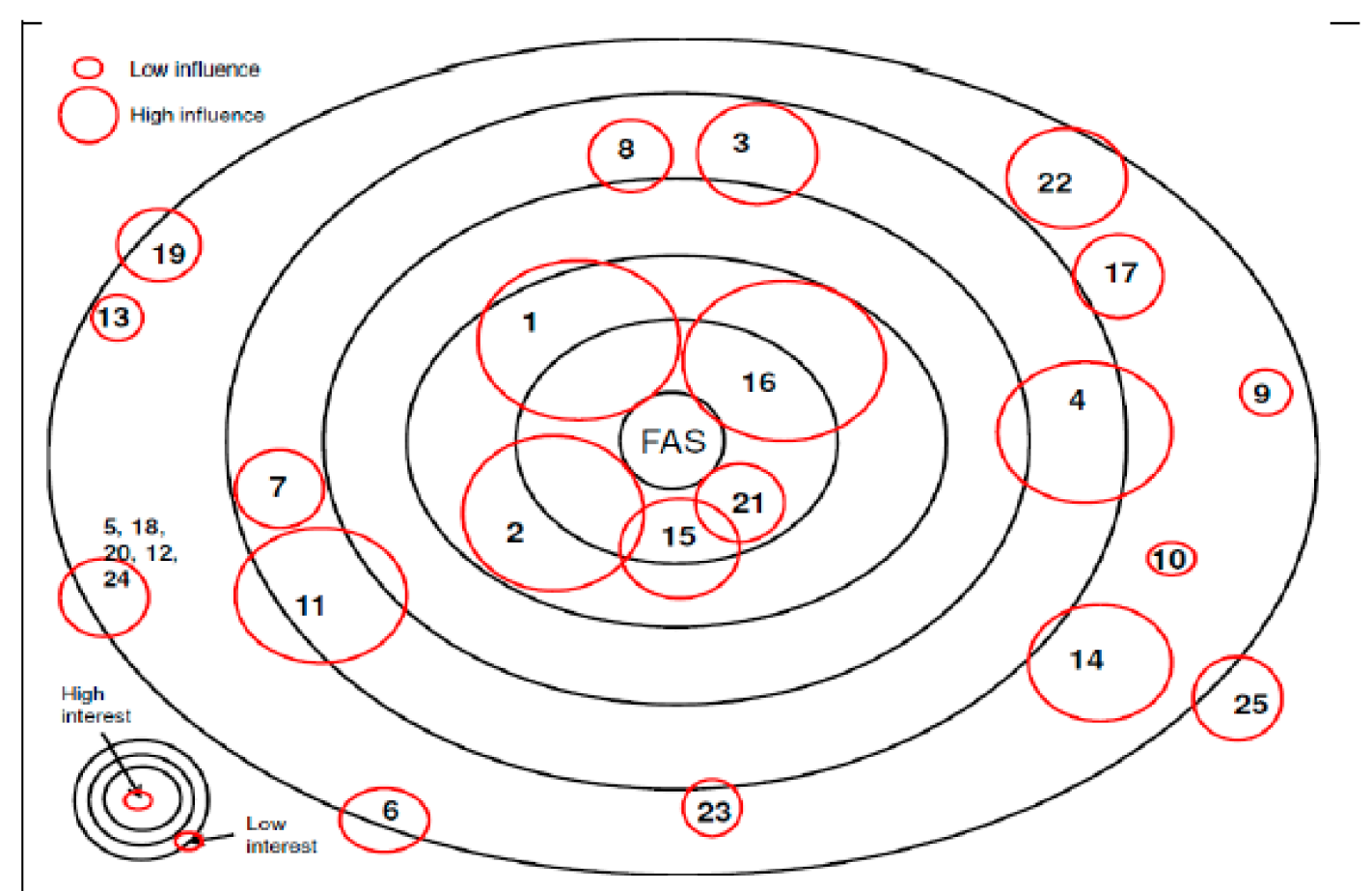

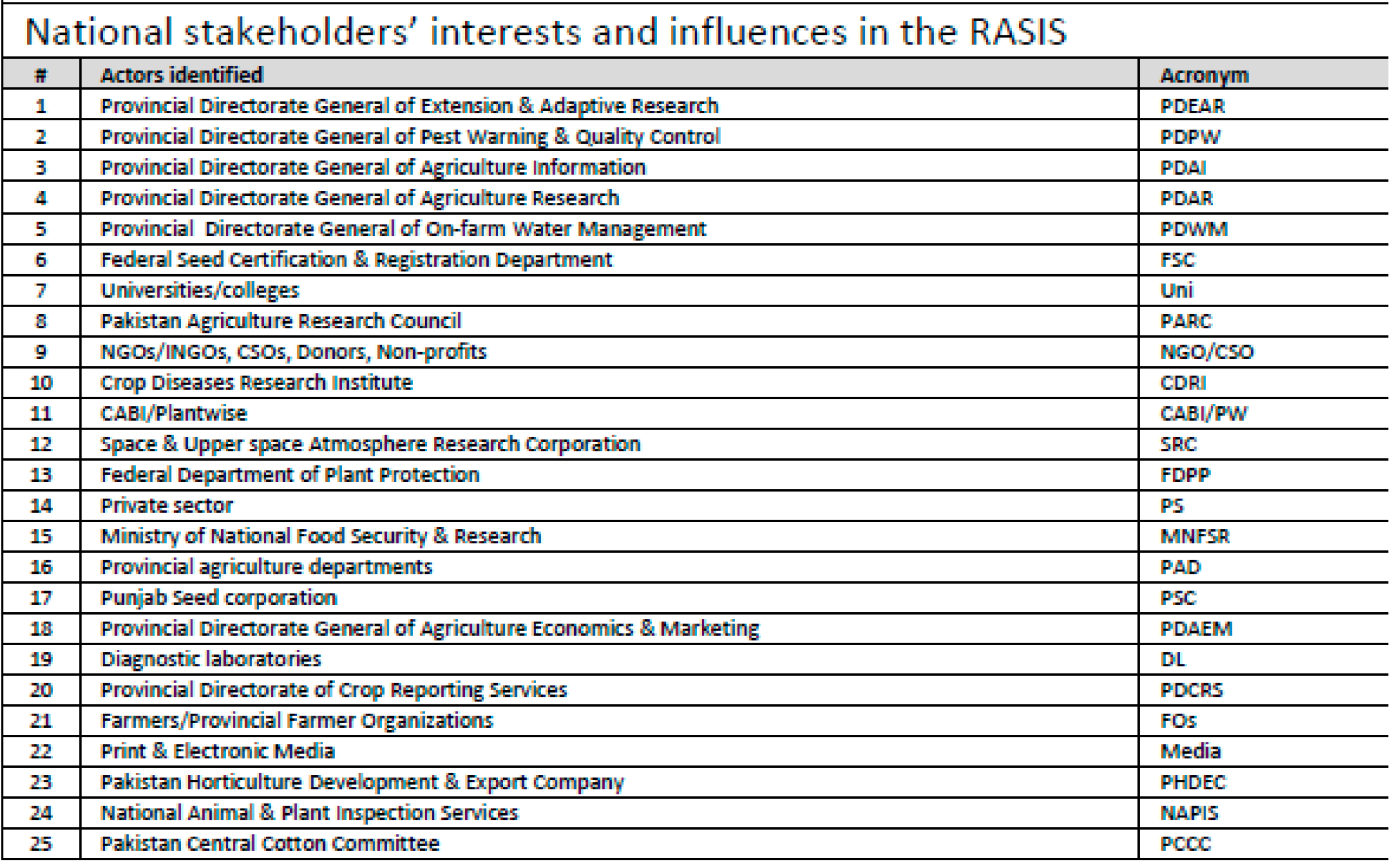

Figure 1. National influence and interest mapping. 


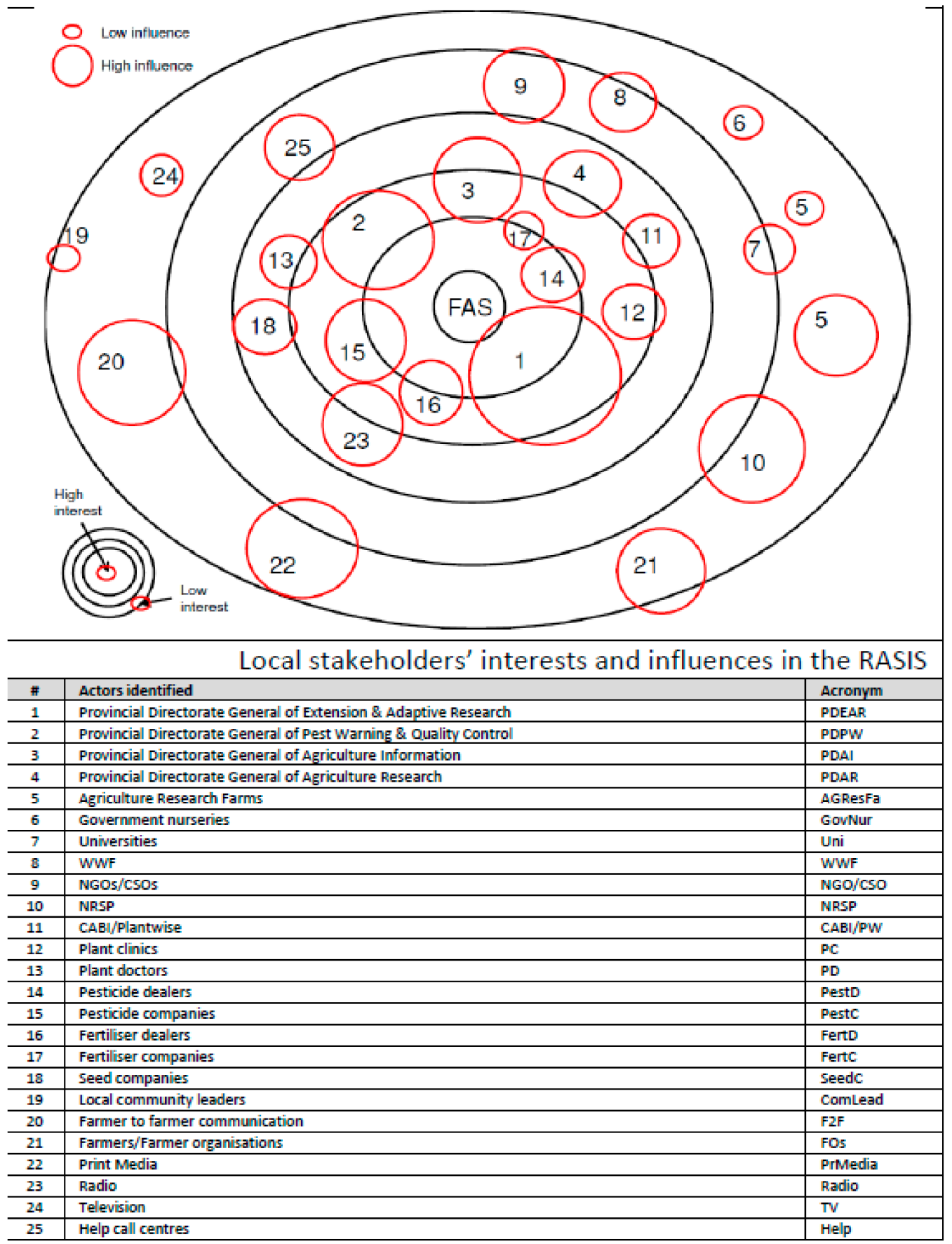

Figure 2. Local influence and interest mapping.

In both the local and national focus group discussions, participants worked in groups before bringing the discussion to debate. Overall, the perception was that the exercises were very useful: many individuals actually mentioned the need to perform these studies internally in the future to understand and improve their own activities in other domains.

The study considers the bias inherent in these workshops held under the CABI banner, thereby possibly distorting participants' view of CABI's position in RAS. Though the mention of CABI was inevitable during the initial workshop introductions, any CABI activity was not mentioned thereafter in order to minimise overrepresentation of $\mathrm{CABI}$ and the Plantwise programme. Mentions of CABI should however not solely be seen as bias. CABI-Pakistan is considered an integral part of the country's research and extension services development, interacting with public, semi-autonomous and academic 
institutions for the last 60 years on a wide range of biological topics, including biological control and integrated pest management (Rehman et al. 2014; Beg and Khan 1982).

The approach firstly attempts to disentangle this network of stakeholders according to their interactions, a concept akin to the Agricultural Innovation System (AIS) (Atari et al. 2009; Ingram 2008; Klerkx et al. 2006; Manderson et al. 2007) that focuses on the interdependence between actors, considered irrelevant if studied individually (Freeman 1987; Lundvall 1992; Nelson and Nelson 2002; Klerkx et al. 2010). This enables studies to unravel physical structures into systemic and dynamic processes, understand practices and behaviours that create change, and deliver knowledge in a local and national setting (D'Allura et al. 2012; Carvalho et al. 2015).

The approach also adapts essential network visualisation techniques (Newcombe 2003) and enables decision makers to gauge a system's capacity to innovate and progress (FAO et al. 2015). They focus on actors' relative influence and interest in decision making activities in the innovation system (Mayers and Vermeulen 2005) to graphically visualise a ranking mechanism given to each participant (Lindenberg and Crosby 1981; Brugha and Varvasovszky 2000; Bourne and Walker 2005; Labarthe 2009). They also establish linkage strengths: a weak-ranked interaction was defined as an interaction that is irregular and on an ad-hoc basis, for example between individuals of the two actors, intermediate interactions defined as official and regular meetings between defined individuals, and a strong interaction was described as a situation where different stakeholders pursue specific activities, such as local or national programmes, that build and strengthen the rural advisory service innovation system. Participants were told intermediately ranked interactions are official and regular meetings between defined individuals, and a strongly ranked interaction is defined by stakeholders pursuing specific activities, such as local or national programmes, that build and strengthen their own activities in the knowledge system. Interactions between stakeholder sectors were scored and mapped, although scores should not be compared between national and local workshops, as the number of groups in the workshops differed

Data were collated onto Microsoft excel in Pakistan, and cleaned and analysed in the SPSS ${ }^{\text {tm }}$ statistical package in the UK. Due to the categorical nature of the dependent and independent variables, the study used cross-tabulated descriptive statistics and binomial $\mathrm{Z}$ tests, applied for two independent population proportions (null hypothesis stating no difference between proportion of national responses and the proportions of local responses) correlated with a $5 \%$ margin of error.

\section{Results}

Both national and local workshop participants listed 25 considerably different stakeholders involved in crop health advisory services (Table 2). National workshop participants focused on high-level institutions, using 'broad-brush' terms for the majority of stakeholders in other sectors, and only occasionally delved into the detail. They mentioned the importance of semi-autonomous bodies. Local focus groups cited specific individual units, and infrequently broadened the scope. 'Provincial agricultural departments' and 'diagnostic laboratories' in the national workshop, and 'plant doctors' and 'plant clinics' in the local workshops were deemed ambiguous terms as they fulfil various roles, and categorised as 'other'. 
Table 2. Composition of national and local workshop organisations.

\begin{tabular}{|c|c|c|c|c|}
\hline \multirow{2}{*}{$\begin{array}{c}\text { Categorisation of } \\
\text { Sector }\end{array}$} & \multicolumn{2}{|c|}{ National Workshop } & \multicolumn{2}{|c|}{ Local Workshop } \\
\hline & $\begin{array}{c}\text { Name of } \\
\text { Stakeholder }\end{array}$ & Number & $\begin{array}{c}\text { Name of } \\
\text { Stakeholder }\end{array}$ & Number \\
\hline Public services & $\begin{array}{c}\text { FDPP; FSC; } \\
\text { MNFSR; PARC; } \\
\text { CDRI; PDEAR; } \\
\text { PDAR; PDPW; } \\
\text { PDAI; PDWM; } \\
\text { PDAEM; PDCRS; } \\
\text { NAPIS }\end{array}$ & 13 & $\begin{array}{c}\text { PDEAR; PDAR; } \\
\text { PDPW; PDAI; } \\
\text { Agricultural } \\
\text { Research Farms; } \\
\text { Government } \\
\text { Nurseries }\end{array}$ & 6 \\
\hline $\begin{array}{l}\text { Semi-autonomous } \\
\text { bodies }\end{array}$ & PSC; PCCC; SRC & 3 & & 0 \\
\hline Private sector & $\begin{array}{c}\text { Private sector; } \\
\text { PHDEC }\end{array}$ & 2 & $\begin{array}{c}\text { Pesticide } \\
\text { companies/dealers; } \\
\text { Fertiliser } \\
\text { companies/dealers; } \\
\text { Seed Companies }\end{array}$ & 5 \\
\hline Non-governmental & $\begin{array}{c}\text { NGO/CSO; } \\
\text { CABI/Plantwise }\end{array}$ & 2 & $\begin{array}{c}\text { NGO/CSO; WWF; } \\
\text { CABI; NRSP }\end{array}$ & 4 \\
\hline Community led & Farmer organisations & 1 & $\begin{array}{l}\text { Community Leader; } \\
\text { Farmer to farmer; } \\
\text { farmer organisations }\end{array}$ & 3 \\
\hline Academic & Universities & 1 & Universities & 1 \\
\hline Media & $\begin{array}{l}\text { Print and electronic } \\
\text { media }\end{array}$ & 1 & $\begin{array}{l}\text { Radio; television; } \\
\text { Print media; Help } \\
\text { call centres }\end{array}$ & 4 \\
\hline Other & $\begin{array}{l}\text { Diagnostic } \\
\text { Laboratories; } \\
\text { Provincial } \\
\text { agriculture } \\
\text { departments }\end{array}$ & 2 & $\begin{array}{c}\text { Plant Clinics; Plant } \\
\text { Doctors }\end{array}$ & 2 \\
\hline $\begin{array}{l}\text { Provincial directorate Ge } \\
\text { Warning \& Quality Contr } \\
\text { Provincial directorate G } \\
\text { Management-PDWM; F } \\
\text { Council-PARC; Non-Go } \\
\text { Institutes-CDRI; Space } \\
\text { Protection-FDPP; Mini } \\
\text { Provincial Directorate G } \\
\text { Reporting Services-PDC } \\
\text { Plant Inspection Services }\end{array}$ & $\begin{array}{l}\text { al of Extension and Ada } \\
\text { f Pesticides-PDPW; Pr } \\
\text { eral of Agriculture Re } \\
\text { eral Seed Certification \& } \\
\text { rnment organisation/Ci } \\
\text { Upper Space Atmosphe } \\
\text { y of National Food Sec } \\
\text { ral of Agriculture Econ } \\
\text {; Pakistan Horticulture D } \\
\text { VAPIS; Pakistan Central }\end{array}$ & $\begin{array}{l}\text { Research- } \\
\text { cial directoro } \\
\text { ch-PDAR; } \\
\text { stration Dep } \\
\text { ociety organ } \\
\text { esearch Coo } \\
\text { \& Research } \\
\text { cs \& Market } \\
\text { lopment \& E } \\
\text { ton Commit }\end{array}$ & $\begin{array}{l}\text { AR; Provincial director } \\
\text { eneral of Agriculture In } \\
\text { vincial directorate Gen } \\
\text { hent-FSC; Pakistan Agr } \\
\text { ions-NGO/CSO; Crop } \\
\text { tion-SRC; Federal De } \\
\text { ANFSR; Punjab Seed C } \\
\text {-PDAEM; Provincial D } \\
\text { rt Company-PHDEC; } \\
\text {-PCCC. }\end{array}$ & $\begin{array}{l}\text { Seneral of Pest } \\
\text { nation-PDAI; } \\
\text { l of On-Farm } \\
\text { tural Research } \\
\text { ease Research } \\
\text { ment of Plant } \\
\text { oration-PSC; } \\
\text { torate of Crop } \\
\text { onal Animal \& }\end{array}$ \\
\hline
\end{tabular}

Stakeholder relationships and their interests/influences provide insights into stakeholders' roles and investments in the innovation system through an intuitive visual representation. The influence/interest (Figures 1 and 2) and interaction mapping exercises provided by the different focus groups portray a picture of perceptions of RAS in the Punjab province of Pakistan from a national (Figure 3) and local perspective (Figure 4). 


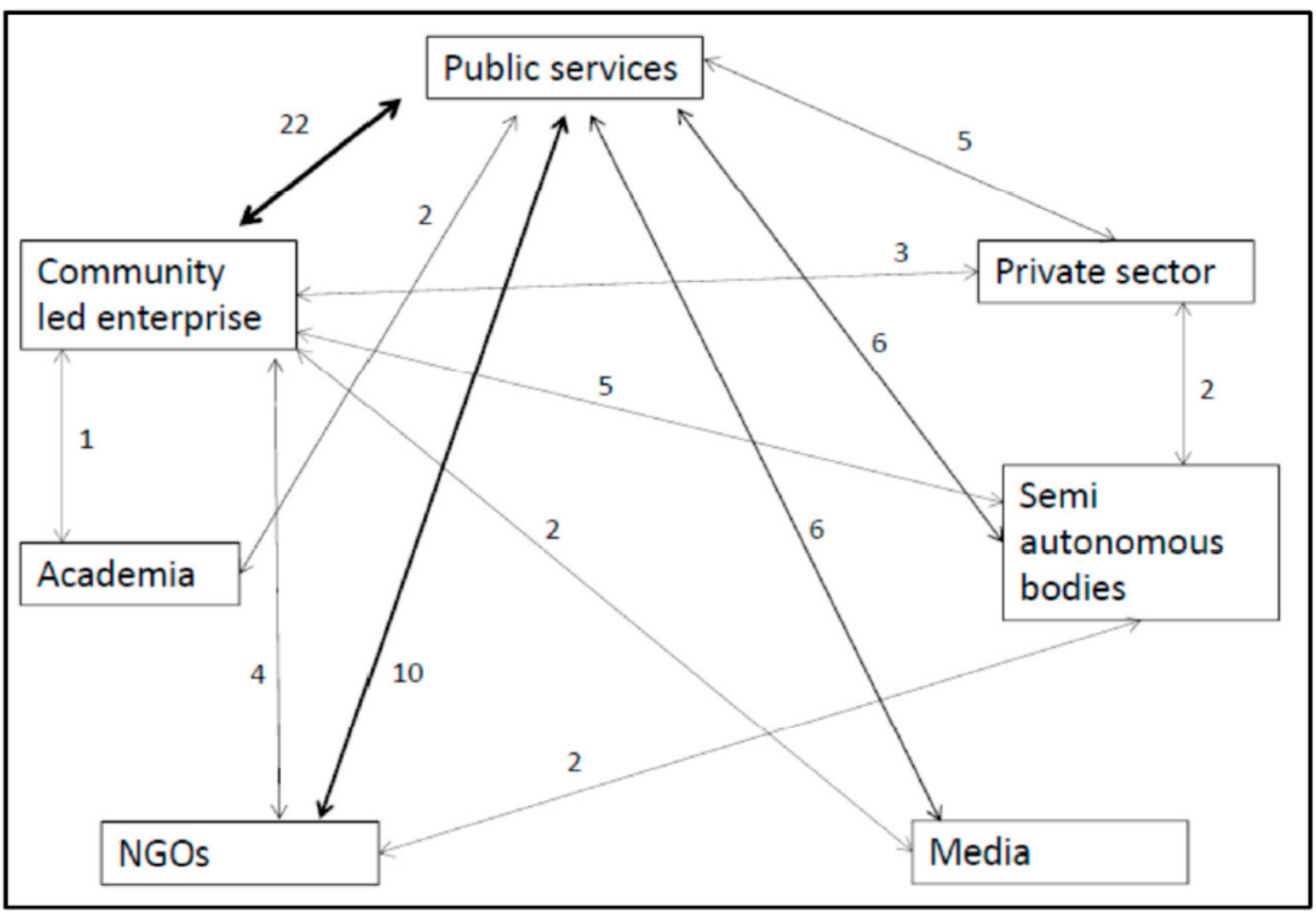

Figure 3. National interactions between sectors with associated scores.

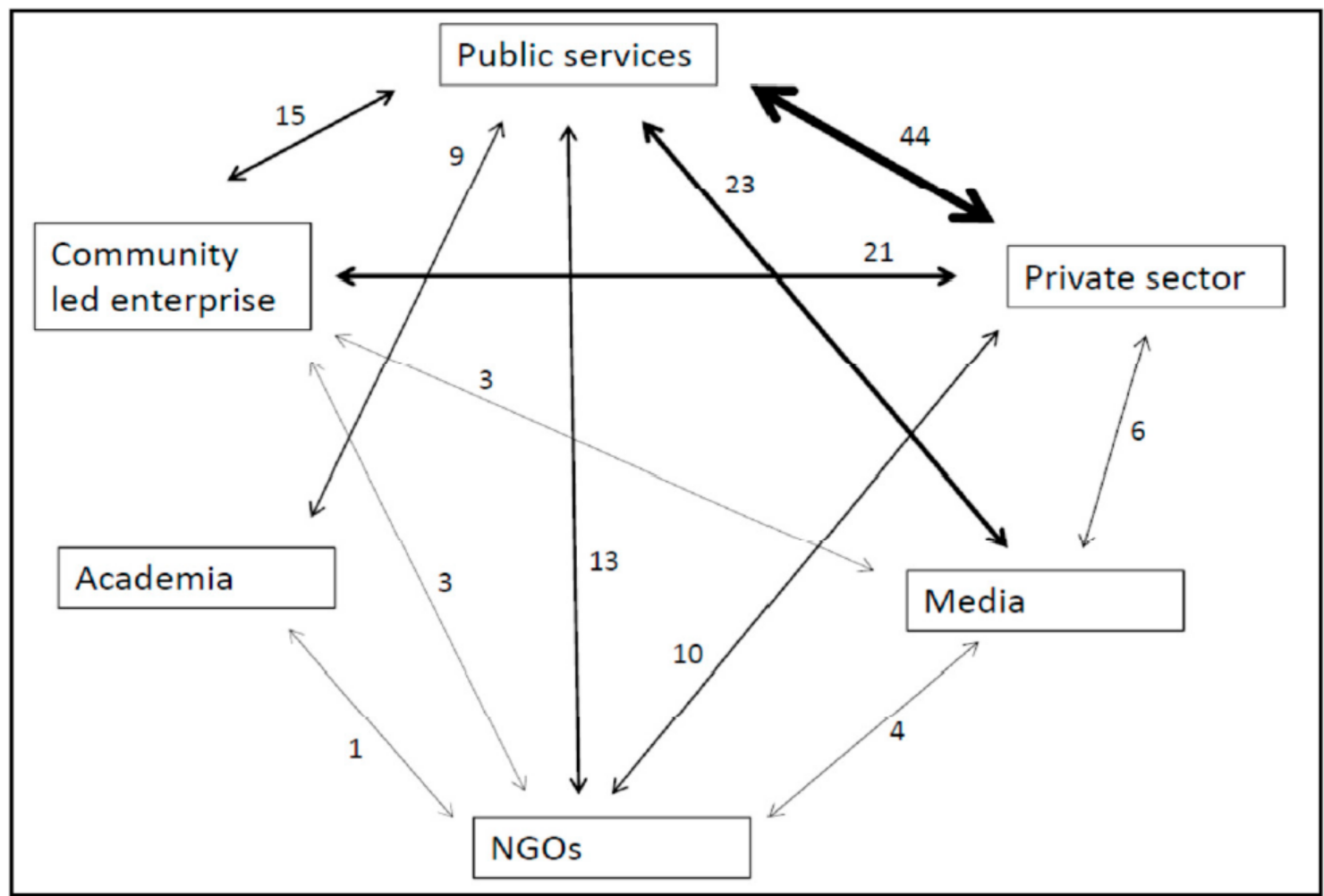

Figure 4. Local interactions between sectors with associated scores. 


\subsection{Public Sector}

Public actors mentioned were different in both exercises: in the national workshop, six of the 13 public stakeholders functioned at a national level; the remaining seven were provincial (Table 2). In the local workshops, all public stakeholders were part of the provincial administration (agricultural research farms and government nurseries are linked to provincial headquarters). The perception of provincial administrations' preponderance in crop health advisory services is statistically significant $(Z=2.01 ; p<0.050)$. Both sets of participants ranked provincial departments as highly influential and interested in crop health advisory services: PDEAR was perceived by all as the most influential and interested actor, with PDPW, the Provincial Directorate for Agricultural Information (PDAI) and the Provincial Directorate for Agricultural Research (PDAR) decreasing in interest and influence accordingly. Agricultural research farms and government nurseries were perceived as weak. Federal actors, such as the Ministry of National Food Security and Research (MNFSR), were seen as highly interested but of limited influence, or to have both little interest and influence, like PARC (Figures 1 and 2).

In both workshop settings, public sector interactions comprise a healthy proportion of all interactions in crop health advisory services (73\% in the national workshop and 68\% in the local one). In the national workshop, public services are mainly linked to community-led enterprise and Non-Governmental Organisations (NGOs) (Figure 3), whilst in the local workshop, the private sector and the media are its two biggest linkages (Figure 4). Moreover, in both workshops, PDEAR and PDPW are the highest interacting members of the public services (interacting internally with other members, as well as externally), with the Federal Department of Plant Protection (FDPP_and PDAI also perceived to have a healthy interaction with surrounding stakeholders. PDAR, government nurseries and agricultural research farms were seen to be fairly disconnected at a local level (Figure 4). Indeed, in spite of a plethora of research stations (63 currently in operation), contacts between public research and extension departments remain scant. Extension services in Pakistan remain "traditional, using old extension methods, top-down and technology-driven approaches and hardly any female field extension staff are employed. Public extension suffers from a lack of in-service training, mobility means, scant career development opportunities, and grossly inadequate operational funds" (Participant X7, national workshop). Moreover, "the link between PARC, provincial extension and provincial research institutes is strengthening, but there is still a frustrating and recognised communication gap between these institutions and non-public sector stakeholders" (Participant X8, national workshop).

In the women's group, PDAR and PDEAR were considered most interested and influential, whilst private fertiliser dealers and companies were seen as interested but with little influence. The link between the private and the public sector was perceived as strong, similarly to men's groups. The female group believed the provincial extension departments shared their information well with multiple sectors, but recognised that the pest warning and quality control departments need to be more aligned and communicative with other stakeholders in the RAS, particularly the extension department. The female group's beliefs and perceptions were not different to the three other male groups.

\subsection{Private Sector}

In the national workshop, the 'private sector' was perceived to have influence but little interest. The linkages within the private sector are strong, particularly at the national level (as fertiliser and pesticides can be produced by the same company). Their links with other sectors of the RAS were weak, representing approximately $15 \%$ of all interactions in the system (the "private sector needs to be more open to collaborating with other sectors, particularly the NGO sector and academia" Participant X9, National workshop). This is in contrast to perceptions of local workshop participants, who identified the five private sector services (Table 2) as interested but largely without influence (excluding pesticide companies who were seen as influential) (Figure 2). The private sector is perceived to interact strongly with four of the five other sectors, a statistically different difference to the national 
workshop perceptions $(Z=5.49 ; p<<0.05)$. In the women's group, the private sector had the largest number of links with other sectors. Indeed, in three of the four local focus groups discussions, the link between agricultural extension and the private sector was highlighted as crucial ("the coordination and information sharing linkages need to be cemented in order for the state to have a much stronger regulatory process and improve the quality and safety of pesticides and fertiliser") (Participant X2, local workshop). However, participants believed the collaboration is held back by the fundamental differences in their approach, one focused on social wellbeing, the other on profits ("I don't believe the agrodealers themselves are geared towards profits, the capitalist approach of growth does not help to serve the farmers in the long term, only profits in the short term" (Participant X3, local workshop). The private sector's role in the system has its advantages, yet there are many issues that need to be tackled at the policy level. For example, micro-finance is unregulated, and farmers are confused about its potential use: "it is not easy for small farmers to get credit due to different and often illogical collateral requirements" (Participant X7, national workshop). Moreover, whilst the private sector has been very active for years in the sale of various farm inputs like seed, fertilizer, pesticides, herbicides and farm machinery, their prices are often too high for the average smallholder to profit from their offers. Additionally, "companies work only with their own contracted farmers or those who have informally agreed to follow their instructions in crop production, and the programmes exclude farmers who do not join their extension activities" (Participant X4, local workshop). The motives behind extension support by the private companies are either to obtain good quality raw materials from growers, and/or to enhance the sale of companies' products. Whilst this is not a problem, as farmers also benefit by gaining technical knowledge and skills and enjoying satisfaction of a guaranteed market for their harvest at reasonable prices, the "system is still largely in favour of the major companies" (Participant X10, national workshop).

Semi-autonomous bodies were thought to have little influence and interest but had good links with community level enterprise and public services such as PARC and NARC. In the local workshop, no semi-autonomous bodies were selected.

\subsection{Non-Government Organisations}

National participants perceived 'NGOs and CSOs' to have little interest and influence. CABI was mentioned separately and was seen to have moderate influence and interest. Over half of civil society's links are with the public sector (the second strongest in the entire exercise), and is seen to be connected to community led enterprise and semi-autonomous bodies. However, these are weak. This is corroborated by individual statements: NGOs, "need to be more open and collaborative with the public sector, and understand the private sector's role in the system" (Participant X6, national workshop). A lot of the NGOs' aims "are not aligned with government short-term and long-term strategies" (Participant X6, national workshop) though NGOs and universities are "increasingly discussing diagnostic and publication support for complicated plant health issues, seed and pesticide testing with plant protection departments, and soil and water testing laboratories at the district level" (Participant X7, national workshop). The NGO sector "does work well with community-led enterprise, particularly farmer organisations, but there is not enough knowledge coming out of this interaction for the government to use as evidence to push for reform." (Participant X6, national workshop).

In contrast with the national workshop, local workshop participants listed three specific actors. These were perceived to have moderate interest (CABI perceived to have the highest interest) and influence (apart from the National Rural Support Programme NRSP which has high influence), although it was acknowledged that "NGOs are more focused on the short term compared to other sectors" (Participant X4, local workshop). This sector was better connected than the national workshop perceived (although not statistically significant), as they account for almost a quarter of all interactions. In the case of farmer organisations for example, they are developing better links with the private sector, from a chemical and crop selling perspective, although they need more support from the government. 


\subsection{Community Level Enterprise}

National workshop participants defined community level activities with one term: 'farmer/farmer organisations' compared to a more detailed assessment by local workshop participants, who coined three separate terms (Table 2). Whereas national participants viewed farmer/farmer organisations as highly interested but not influential (Figure 1), local participants viewed them as highly influential and less interested (Figure 2). In the national workshop, community-led enterprise interactions are linked to every other stakeholder group (Figure 3), compared to the local workshops, where community-led enterprise interactions maintain a strong connection with the private and public sectors, but surprisingly weak elsewhere (Figure 4). The difference in interaction totals between both workshops is statistically significant $(Z=4.04 ; p<<0.05)$. It was stated farmers "mostly interact with each other for best practice information sharing on crop health" (Participant X1, local workshop) and to get benefits from each other experiences. Farmers mainly interact with institutions such as PDEAR and the private sector "which provide technical assistance to the farmers and also input for their crops" (Participant X1, local workshop). Farmer organizations have their own manifesto and rules but mostly lack human resources and an understanding of political and administrative frameworks, so they are heavily reliant on PDEAR and the private sector for their crop health and procurement issues: "Although farmers are a crucial community for the success of this nation, they rely almost exclusively on PDEAR and the private sector for availability of high-quality agricultural inputs, vocational training for smallholder producers, agricultural financing, and access to technology" (Participant X2, local workshop).

\subsection{Media}

National workshop participants labelled media simply through 'print/electronic media', whereas local workshop participants defined media through four terms: 'radio', 'print', 'television' and 'help call centres' (Table 2). Both workshops agree that media may not have much interest in rural advisory services, but have moderate influence (apart from television which has low influence).

There is a mild significant difference $(Z=2.12 ; p<0.05)$ between national and local perception of interactions of the media with other sectors in the plant health system as local workshops perceived media to be better connected than national participants. Both workshops agree however that there is a strong interaction with public services (Figures 1 and 2).

\subsection{Academic}

Both sets of workshops agreed that the academic sector, defined by the term 'Universities', had low influence and interest in the RAS system, and weak interactions with different sectors. In both workshops, the most important interaction is with the public sector (PDPW in the national workshop and PDAR in the local workshop).

\section{Discussion}

This section initially focuses on the approach's ability to highlight key issues in Pakistan as well as on decentralisation processes in general. The discussion then investigates how this approach helps development activities understand their integration into a national or local system.

\subsection{Highlighting Decentralisation Issues}

This approach highlights key decentralisation issues internationally and within Pakistan, such as the strength of sub-federal public services in ensuring RAS: both national and local partners recognised the importance of provincial over federal authorities to carry out specific RAS activities (Mengal et al. 2014). The perception of the preservation of a top down approach is also representative. In Pakistan, weak/confusing federal direction and communication to provincial administrations, seldom involving local representatives, further fuels the perception of top-down decision-making 
decentralisation was keen to remove (Gill and Mushtaq 1998; Luqman et al. 2007; Abbas et al. 2009). This is important to consider in light of the deficiency of advisory services in smallholder agriculture in Pakistan (Davidson et al. 2001; Davidson and Ahmad 2002; Abbas et al. 2009; Burton et al. 2012), the increased administrative bureaucracy, and local staff's lack of clarity and low morale in their extension roles (Shahbaz et al. 2011). In Pakistan, effective and efficient decentralisation as a tool in the governance of natural resources and information flow will only be fully realised when there is engagement with local communities and administrations about local issues (Nagrah et al. 2016; Wahid et al. 2017). This statement has been taken to heart by some, notably Farmer Services Centers (FSCs). These were developed to engage with local communities in the Kyber Pakhtunkhwa province (Intikhab 2014; Shah et al. 2016) and are fulfilling vital common services, even if there is still room for improvement (Khan et al. 2017; Shah et al. 2016).

The study also highlights a lack of understanding of roles in crop health advisory services, demonstrated by the over-simplification of certain sectors' identities. For example, local workshop participants dissected the actors in the private sector, distinguishing between companies and individuals; they even separated actors according to industry, highlighting seeds, agrochemicals and fertilisers. National level participants on the other hand, grouped privately owned/run services simply as 'the private sector', and did the same in the NGO and media sectors. This may be for two reasons: firstly, an increased awareness of public sector constraints at the local level due to decentralisation and the importance to address these by collaboration with other sectors, particularly with the private sector (Riaz 2010). Indeed, public services have been running crop health RAS since Pakistan's independence. That is, until the successful privatisation of agricultural input supplies in the 1970s during the green revolution (Riaz 2010), which went on to dominate private sector extension activities, offering comprehensive plant protection packages that in some cases cut out the need for the public sector (Davidson et al. 2001). This situation had its advantages (Khooharo et al. 2008; Zhou 2009) and limitations (Davidson et al. 2001; Riaz 2010; Khooharo 2008; Ali et al. 2011).

At the national level, whilst an awareness of sectoral collaboration is not present in the results (as demonstrated by the national workshop's worryingly simplistic grouping of 'private sector'), the situation is nuanced: indeed, certain participants did acknowledge their lack of knowledge openly in the group sessions, especially on the topic of the private and NGO sectors. However, their knowledge focuses on complex national rural challenges, broaching the subjects of semi-autonomous bodies, or microfinance, whose regulatory processes are usually overseen and discussed at the federal level (Hussein 2009).

Secondly, this over simplification could be representative of a wider perception problem in Pakistan's institutional governance and communication in multi-sectoral domains. A recent national innovation system study states robust national/local technology transfers, downstream diffusion, and entrepreneurship activities are all vital in order to build and maintain strong collaborations in diverse sectors in Pakistani innovation systems (U1-Haq et al. 2014). In crop health, certain national level institutions are equipped to deal with this challenge: The National Agricultural Research Council (NARC) for example set up local and national commercial initiatives to bridge the gaps and deal with the deficiencies in innovation and technology transfer, such as the semi-autonomous 'Pakistan Horticulture Development and Export Company'. Whilst these initiatives are important to the overall federal strategy, they focus almost exclusively on national level issues. This is aptly demonstrated by their absence in local discussions, and pertinently highlights communication and governance issues mentioned above.

These two issues reveal the ambiguity that exists in integrating collaborative approaches most effectively, particularly between local and national settings in the majority of knowledge systems around the world. The insights gleaned from this study are especially important considering current innovation network research and its effect on knowledge (Esparcia 2014) and entrepreneurship (Autio et al. 2014). Indeed, focusing the attention of theoretical, managerial and policy implications 
of innovation on a particular domain, crop health, could lead to a change in many national public administrations' simplistic perceptions of different sectoral activities in the future.

\subsection{Highlighting an Initiative's Position and Durability in a System}

The Plantwise programme is focused on developing three main themes in collaboration with federal and provincial authorities at the national and local levels: the field based plant clinic, which gives crop health advice to individual farmers, the online knowledge platforms-namely the open-access Knowledge Bank (www.plantwise.org/knowledgebank) and Plantwise Online Management System (www.plantwise.org/POMS)—and a holistic Plant Health Systems approach, dedicated to improving communication between key sectors in crop health services. The responsibility for the implementation of clinics is usually held at the provincial level due to its field activities, although national partners are generally kept aware of current status. Both online platforms serve both the local and national levels as they register clinic query results for local and national level enquiries; they also provide open access crop health information on continental and national issues. Finally, the plant health system approach also deals with both local and national partners, as it attempts to foster a general collaborative approach on crop health.

This methodology could be useful for local and national governance programmes to understand and integrate activities more efficiently. For Plantwise, these results can help programme implementation teams understand local and national actors' goals, influences and interests, enabling stronger and clearer linkages. It would also allow a wider use of comprehensive knowledge platforms such as the Knowledge Bank. The methodology's results are vital for programmes to acknowledge their places in the local and national system in order to continually integrate themselves.

\subsection{Recommendations for Advisory Services}

A cohesive understanding of relationships and roles in crop health advisory services is vital to enable the international, national and local community of actors to design and maintain efficient systems. Indeed, a fragmented understanding and subsequent implementation of stakeholder activities in crop health are limiting the country's ability to provide a service deemed acceptable under global and national pathways to development. Differences highlighted throughout the study were traced back to a lack of awareness and understanding by national participants of the capacity, needs and collaborations of advisory services at the local level. National interests should for example analyse local participants' positive perceptions of the private sector, having been in contact with representatives, including agrodealers, far more often. Knowledge created and implementation activities run locally by NGOs and farmer organisations could also be the subject of a more targeted awareness campaign by the public and private sectors as well. Crop health actors involved in rural advisory services in Pakistan could potentially be well served by investigating perceptions of stakeholders who are located at the other end of knowledge value chain, the end users. In essence, an improved understanding of ground level partnerships for policy strategizing at the federal level needs to be combined effectively with a clear understanding of provincial administrations roles in planning and budgeting responsibilities in order to streamline advisory services.

\subsection{Approach Considerations}

The approach used to investigate the difference in perceptions between local and national stakeholders in the crop health advisory services of Pakistan is innovative in its combination of methodologies, adapting readily available and accessible quantitative tools with low cost qualitative assessment activities. Their use in comparing local and national settings is experimental and subject to the devolution climate in many low-and-middle-income countries. The analysis can be repeated, and their interpretation compared to previous results using the same methodologies (a very similar set of stakeholders would need to be invited in order to reduce bias, or improve replicability of experiment), giving the approach a pragmatic use for development initiative to measure their impact. Finally, this 
tool was used on a decentralised model. Other models could also compare to test the validity of the method in the future. Moreover, the model is based on perceptions of interested stakeholders, which can sometimes emphasise bias. In order to link to other known approaches in agricultural innovation system debate, more in-depth tools should incorporate national and local social network analyses. Moreover, this approach was keen to investigate perceptions through a gender lens. Unfortunately, it was not possible to conduct such a test. Further efforts with this approach should attempt to incorporate these standards, as Kingiri (2013) does with AIS.

\section{Conclusions}

The theoretical construct of a RAS system in the academic literature unfortunately does not translate into practice often enough: whilst it is the scientific community's responsibility to describe and analyse the current RAS outlook, it should also look to build better descriptive and analytical systems that are accessible and available to the non-academic community. This study attempted to develop and test an approach to analyse and understand national and local perceptions of a crop health advisory service system that can be replicated in many different settings, including other countries and other rural advisory knowledge systems. The authors consider this approach an important contribution to the literature as it enables participants to have a detailed yet pragmatic understanding of a knowledge system, analyses perception differences that are usually the basis for political conflicts and power struggles, and forces individuals to reconsider their assumptions on systemic processes. It also gives initiatives, such as Plantwise, an opportunity to analyse the status of their national and local efforts to improve crop health advisory services. Finally, whilst this study could not accommodate gender-disaggregated results, the authors believe it is vital to integrate these types of socio-economic factors in order to get a more comprehensive understanding of RAS.

Author Contributions: J.G. was the main researcher and writer for this study. P.D. and S.C. supported the development of the study's thought processes, whilst I.A. helped during the national workshop, and N.A. helped throughout, in particular for the local workshops in Jhang and Bahawalpur.

Funding: This research was funded by and supported by UK Department for International Development (DfID), Swiss Agency for Development Cooperation (SDC), European Commission (DG DEVCO), Netherlands Ministry of Foreign Affairs (DGIS), Irish Aid, International Fund for Agricultural Development (IFAD) and the Australian Centre for International Agricultural Research (ACIAR).

Conflicts of Interest: The authors declare no conflict of interest.

\section{References}

Abbas, Mazher, Toheed Elahi Lodhi, Khalid Mahmood Aujla, and Shawana Saadullah. 2009. An agricultural extension programs in Punjab. Pakistan Journal of Life and Social Sciences 7: 1-10.

Ali, Shoukat, Munir Ahmad, and Muhammad Luqman. 2011. Role of private extension system in agricultural development through advisory services in the Punjab, Pakistan. Pakistan Journal of Sciences 63: 70-73.

Amjad, Rashid, Ghulam M. Arif, and Usman Mustafa. 2008. Does the Labor Market Structure Explain Differences in Poverty in Rural Punjab? Islamabad: Pakistan Institute of Development Economics.

Anaeto, Frank C., C. C. Asiabaka, F. N. Nnadi, J. O. Ajaero, O. O. Aja, F. O. Ugwoke, M. U. Ukpongson, and A. E. Onweagba. 2012. The role of extension officers and extension services in the development of agriculture in Nigeria. Journal of Agricultural Research 1: 180-85.

Atari, D. O. Atari, Emmanuel K. Yiridoe, Shawn Smale, and Peter N. Duinker. 2009. What motivates farmers to participate in the Nova Scotia environmental farm plan program? Evidence and environmental policy implications. Journal of Environmental Management 90: 1269-79. [CrossRef] [PubMed]

Autio, Erkko, Martin Kenney, Philippe Mustar, Don Siegel, and Mike Wright. 2014. Entrepreneurial innovation: The importance of context. Research Policy 43: 1097-108. [CrossRef]

Beg, Munir, and Ali Khan. 1982. Natural enemies of paddy pests in Pakistan. Pakistan Journal of Agriculture Research 3: 84-95.

Bourne, Lynda, and Derek H. T. Walker. 2005. Visualising and mapping stakeholder influence. Management Decision 43: 649-60. [CrossRef] 
Brugha, Ruairí, and Zsuzsa Varvasovszky. 2000. Stakeholder Analysis: A Review. Health Policy Plan 15: $239-46$. [CrossRef]

Burton, Martin, Turi Fileccia, Aidan Gulliver, Marat Qamar, and Ali Tayyab. 2012. Pakistan: Priority Areas for Investment in the Agricultural Sector. Rome: Food and Agriculture Organization of the United Nations.

Carvalho, Nuno, Luisa Carvalho, and Sandra Nunes. 2015. A methodology to measure innovation in European Union through the national innovation system. International Journal of Innovation and Regional Development 6: 159-80. [CrossRef]

Chauhan, Khalid. 2014. Gender Inequality in the Public Sector in Pakistan: Representation and Distribution of Resources. Berlin: Springer.

Cleland, John, and Kazuyo Machiyama. 2017. The Challenges Posed by Demographic Change in sub-Saharan Africa: A Concise Overview. Population and Development Review 43: 264-86. [CrossRef]

D'Allura, Giorgia, Marco Galvagno, and Arabella Mocciaro Li Destri. 2012. Regional Innovation Systems: A Literature Review. Business Systems Review 1: 139-56.

Danielsen, Solveig, and Frank B. Matsiko. 2016. Using a plant health system framework to assess plant clinic performance in Uganda. Food Security 8: 345-59. [CrossRef]

Davidson, Andrew P., and Munir Ahmad. 2002. Effectiveness of public and private sector agricultural extension: Implications for privatisation in Pakistan. The Journal of Agricultural Education and Extension 8: 117-26. [CrossRef]

Davidson, Andrew P., Munir Ahmad, and Tanvir Ali. 2001. Dilemmas of Agricultural Extension in Pakistan: Food for Thought. Washington, DC: Agricultural Research and Extension Network.

Department of Agricultural Extension Punjab. 2016. Available online: www.agripunjab.gov.pk (accessed on 3 November 2016).

Esparcia, Javier. 2014. Innovation and networks in rural areas. An analysis from European innovative projects. Journal of Rural Studies 34: 1-14. [CrossRef]

Fanzo, Jessica, Quinn Marshall, Darja Dobermann, Joyce Wong, and Rafael I. Merchan. 2015. Integration of nutrition into extension and advisory services: A synthesis of experiences, lessons, and recommendations. Food and Nutrition Bulletin 36: 120-37. [CrossRef] [PubMed]

FAO. 2015. Women in Agriculture in Pakistan. Available online: www.fao.org/3/a-i4330e.pdf (accessed on 3 November 2016).

FAO, IFAD, and WFP. 2015. The State of Food Insecurity in the World 2015: Meeting the 2015 International Hunger Targets: Taking Stock of Uneven Progress. Rome: Food and Agriculture Organization of the United Nations.

Finegold, Cambria, Mary Lucy Oronje, Margo C. Leach, Teresia Karanja, Florence Chege, and Shaun Hobbs. 2015. Plantwise Knowledge Bank: Building sustainable data and information processes to support plant clinics in Kenya. Agricultural Information Worldwide 6: 96-101.

Freeman, Christopher. 1987. Technology Policy and Economic Performance: Lessons from Japan. London: Pinter.

Gill, Mushtaq Ahmad, and Khurram Mushtaq. 1998. A Case Study of Punjab Agriculture Department. Lahore: Pakistan National Programme International Irrigation Management Institute.

Global Forum of Rural Advisory Services. 2016. Five Key Areas for Mobilising the Potential of Rural Advisory Services. Lausanne: Global Forum of Rural Advisory Services.

Hassan, Yousuf Zakaria Muhammad, Tanvir Ali, and Munir Ahmad. 2007. Determination of participation in agricultural activities and access to sources of information by gender: A case study of district Muzaffargarh. Pakistan Journal of Agricultural Sciences 44: 664-69.

Hussein, Maliha Hamid. 2009. State of Microfinance in Pakistan. Available online: http://inm.org.bd/wpcontent/uploads / 2015/09/Pakistan.pdf (accessed on 3 November 2016).

Ingram, Julie. 2008. Agronomist-farmer knowledge encounters: An analysis of knowledge exchange in the context of best management practices in England. Agriculture and Human Values 25: 405. [CrossRef]

International Fund for Agricultural Development. 2013. Smallholders, Food Security and the Environment. Rome: United Nations Environment Programme.

Intikhab, Amir. 2014. Farm Services Centres for all KP Districts. Available online: https:/ /www.dawn.com/ news/1082993 (accessed on 3 November 2016).

Jones, Gwyn E., and Chris Garforth. 1997. The History, Development, and Future of Agricultural Extension. Rome: United Nations Food and Agriculture Organisation. 
Kania, Jozef, Krystyna Vinohradnik, and Agnieszka Tworzyk. 2014. Advisory services in agricultural system of knowledge and information in Poland. Paper presented at 11th European IFSA Symposium, Berlin, Germany, April 1-4.

Khan, Sajjad Ali. 2015. Devolution Plan 2000: Dictatorship, democracy, and the politics of institutional change in Pakistan. Development in Practice 25: 574-86. [CrossRef]

Khan, Muhammad Zafarullah, Tario Shah, Asif Nawaz, Rehmat Ullah, Ikram Haq, Khattam Haq, and Abdur Rahman. 2017. Farmers' empowerment under FSC approach regarding selected agricultural inputs in Khyber Pakhtunkhwa, Pakistan. International Journal of Agricultural and Environmental Research 3: 250-59.

Khooharo, Ali. 2008. A Study of Public and Private Sector Pesticide Extension and Marketing Services for Cotton Crop. Ph. D. thesis, Agricultural University of Tandojam, Sindh, Pakistan.

Khooharo, Ali, Roger Memon, and Mohammed Lakho. 2008. An assessment of farmers' level of knowledge about proper usage of pesticides in Sindh Province of Pakistan. Sarhad Journal of Agriculture 24: 531-39.

Kingiri, Ann N. 2013. A Review of Innovation Systems Framework as a Tool for Gendering Agricultural Innovations: Exploring Gender Learning and System Empowerment. The Journal of Agricultural Education and Extension 19: 521-41. [CrossRef]

Klerkx, Laurens, Karin De Grip, and Cees Leeuwis. 2006. Hands off but Strings Attached: The Contradictions of Policy-induced Demand-driven Agricultural Extension. Agriculture and Human Values 23: 189-204. [CrossRef]

Klerkx, Laurens, Noelle Aarts, and Cees Leeuwis. 2010. Adaptive management in agricultural innovation systems: The interactions between innovation networks and their environment. Agricultural Systems 103: 390-400. [CrossRef]

Labarthe, Pierre. 2009. Extension services and multifunctional agriculture. Lessons learnt from the French and Dutch contexts and approaches. Journal of Environmental Management 2: 193-202. [CrossRef]

Lamontagne-Godwin, Julien, Frances Williams, Bandara Willoru Mudiyansele Palitha Thilakasiri, and Ziporah Appiah-Kubi. 2017. Quality of extension advice: A gendered case study from Ghana and Sri Lanka. The Journal of Agricultural Education and Extension 23: 7-22. [CrossRef]

Lamontagne-Godwin, Julien, Frances Williams, Naeem Aslam, Sarah Cardey, Peter Dorward, and M. Almas. 2018. Gender differences in use and preferences of agricultural information sources in Pakistan. The Journal of Agricultural Education and Extension 24: 419-34. [CrossRef]

Leeuwis, Cees, and Anne van den Ban. 2004. Communication for Rural Innovation: Rethinking Agricultural Extension. Oxford: Blackwell Science.

Lindenberg, Marc, and Benjamin Crosby. 1981. Managing Development: The Political Dimension. Hartford Connecticut: Kumarian Press.

Looney, Robert E. 1999. Private sector investment in Pakistani agriculture: The role of infrastructural investment. Journal of Development Science 15: 189-204.

Lundvall, Bengt-Åke. 1992. Towards a Theory of Innovation and Interactive Learning. Introduction in National Systems of Innovation. London: Printer.

Luqman, Muhammad, Ahmed Kafeel, Mohammed Ashraf, and Zareef Khan. 2007. Effectiveness of decentralised agricultural extension system (a case study of Pakistan). African Crop Science Conference Proceedings 8: 1465-72.

Manderson, Andrew K., Alec D. Mackay, and Alan P. Palmer. 2007. Environmental whole farm management plans: Their character, diversity, and use as agri-environmental indicators in New Zealand. Journal of Environmental Management 82: 319-31. [CrossRef] [PubMed]

Mayers, James, and Sonja Vermeulen. 2005. Stakeholder Influence Mapping. London: International Institute of Environment and Development.

Mengal, Ahmed, Zaheeruddin Mirani, and Habibullah Magsi. 2014. Historical overview of agricultural extension services in Pakistan. The Macrotheme Review 3: 23-36.

Mur, Remco, Frances Williams, Solveig Danielsen, Gabrielle Audet-Bélanger, and Joseph Mulema. 2015. Listening to the Silent Patient: Uganda's Journey towards Institutionalizing Inclusive Plant Health Services. Wallingford: CABI.

Nagrah, Aatika, Anita M. Chaudhry, and Mark Giordano. 2016. Collective Action in Decentralized Irrigation Systems: Evidence from Pakistan. World Development 8: 282-98. [CrossRef]

Nelson, Richard R., and Katherine Nelson. 2002. Technology, institutions, and innovation systems. Research Policy 31: 265-72. [CrossRef]

Newcombe, Robert. 2003. From client to project stakeholders: A stakeholder mapping approach. Construction Management and Economics 21: 841-48. [CrossRef] 
Oerke, Erich-Christian. 2006. Crop losses to pests. The Journal of Agricultural Science 144: 31-43. [CrossRef]

Pakistan Bureau of Statistics. 2019. Jhang and Bahawalpur District Profiles. Available online: http://www. pbscensus.gov.pk/sites/default/files/bwpsr/punjab/BAHAWALPUR_SUMMARY.pdf (accessed on 4 March 2019).

Peterman, Amber, Agnes Quisumbing, Julia Behrman, and Ekonya Nkonya. 2011. Understanding the complexities surrounding gender differences in agricultural productivity in Nigeria and Uganda. Journal of Development Studies 47: 1482-509. [CrossRef]

Plantwise. 2015. Available online: www.plantwise.org (accessed on 3 November 2016).

Qureshi, Sarfraz Khan, and Ghulam Mohammad Arif. 2001. Profile of Poverty in Pakistan. Islamabad: Pakistan Institute of Development Economics.

Rehman, Hafiz Mahmood Ur, Riaz Mahmood, and Muhammad Razaq. 2014. Occurrence, monitoring techniques and management of Dasineura amaramanjarae Grover (Diptera: Cecidomyiidae) in Punjab, Pakistan. Pakistan Journal of Zoology 46: 45-52.

Riaz, Muhammad. 2010. The role of the private sector in agricultural extension in Pakistan. Rural Development News 1: 15-22.

Rivera, William M. 2011. Public Sector Agricultural Extension System Reform and the Challenges Ahead. The Journal of Agricultural Education and Extension 17: 165-80. [CrossRef]

Rossi, Vittorio, Tito Caffi, and Francesca Salinari. 2012. Helping farmers face the increasing complexity of decision-making for crop protection. Phytopathologia Mediterranea 51: 457-479.

Schrempf, Benjamin, David Kaplan, and Doris Schroeder. 2013. National, Regional, and Sectoral Systems of Innovation-An Overview. Brussel: European Comission.

Shah, Tariq, Jianping Tao, Muhammand Zafarullah Khan, and Farooq Shah. 2016. Analysing the Performance of Member and Non-member Farming Community of Model Farm Services Centre in District Dera Ismail Khan. Pakistan Journal of Applied Environmental and Biological Sciences 6: 191-201.

Shahbaz, Baar, and Salman Ata. 2014. Enabling Agricultural Policies for Benefiting Smallholders in Dairy, Citrus and Mango Industries of Pakistan. Available online: http:/ /www.vises.org.au/documents/2014_Sept_ Background_Paper_1_Agriculture_Extension_Services_Pakistan.pdf (accessed on 3 November 2016).

Shahbaz, Babar, Tanvir Ali, and Abid Suleri. 2011. Dilemmas and challenges in forest conservation and development interventions: Case of Northwest Pakistan. Forest Policy and Economics 13: 473-78. [CrossRef]

Spielman, David, Javier Ekboir, and Kristin Davis. 2009. The art and science of innovation systems inquiry: Application to Sub-Saharan agriculture. Technology in Society 31: 399-405. [CrossRef]

Sustainable Development Goals. 2017. Available online: https://sustainabledevelopment.un.org/ content/documents /21252030\%20Agenda\%20for\%20Sustainable\%20Development\%20web.pdf (accessed on 3 November 2016).

Sutherland, Lee-Ann, Jane Mills, Julie Ingram, Rob J. F. Burton, Janet Dwyer, and Kirsty Blackstock. 2013. Considering the source: Commercialisation and trust in agri-environmental information and advisory services in England. Journal of Environmental Management 118: 96-105. [CrossRef] [PubMed]

Ul-Haq, Muhammad Anwar, Yan Jingdong, Nazar Hussain Phulpoto, and Muhammad Usman. 2014. Analysing National Innovation System of Pakistan. Developing Country Studies 4: 133-38.

Wahid, Abdul, Muhammand Ahmad, Noraini Bt. Abu Talib, Iqtidar Ali Shah, Muhammad Tahir, Farzand Ali Jan, and Muhammad Qaiser Saleem. 2017. Barriers to empowerment: Assessment of community-led local development organizations in Pakistan. Renewable and Sustainable Energy Reviews 74: 1361-70. [CrossRef]

War, A. Rashid, Gaurav Kumar Taggar, Mohd Yousuf War, and Barkat Hussain. 2016. Impact of climate change on insect pests, plant chemical ecology, tritrophic interactions and food production. International Journal of Clinical and Biological Science 1: 16-29.

Zhou, Yuan. 2009. Improving the livelihood of smallholder farmers. Agriculture Extension. Syngenta Foundation for Sustainable Agriculture 2010: 1-15.

(C) 2019 by the authors. Licensee MDPI, Basel, Switzerland. This article is an open access article distributed under the terms and conditions of the Creative Commons Attribution (CC BY) license (http:/ / creativecommons.org/licenses/by/4.0/). 